\title{
Education for Sustainability at a Montessori Primary School: From Silos to Systems Thinking
}

\author{
Elaine Lewis \\ Supervisors \\ Professor Simone Volet \\ Dr Catherine Baudains \\ Dr Caroline Mansfield
}

\begin{abstract}
This research investigated Education for Sustainability (EfS) at an independent Montessori primary school, located in the Perth metropolitan area of Western Australia. A longitudinal case study involving analysis of data from a 20-year period was conducted to determine the effectiveness of EfS. Historical information about EfS at the school from 1990 to 2005 was examined, with the main focus of the study being on the impact of the Australian Sustainable Schools Initiative (AuSSI) between 2005 and 2009. AuSSI promotes a whole school, whole systems thinking approach to EfS.

Three school-based issues in EfS were studied. First, the research aimed to determine what elements of EfS were in operation in the school prior to involvement in AuSSI. Second, student outcomes including engagement with whole systems thinking, attitudes and values, knowledge and understandings, and skills and behaviours related to EfS, were investigated during the first 5 years of participation in AuSSI. Third, teacher perceptions of the EfS program, including engagement with whole systems thinking, were examined during this same time period.

A case study approach was employed to enable in-depth investigation of EfS in the life of the school prior to, during and post implementation of AuSSI. This approach facilitated revelation of participants' lived experiences, their perceptions and understandings of EfS, as well as detailed information about student outcomes in EfS. Case study methodology was also compatible with the culture and processes of the participating school and provided an opportunity for utilising a whole systems thinking approach. Data was gathered from a range of sources, through surveys, interviews, observation and document analysis over a 5-year period. The total participants included 11 teachers and 75 students.

The research identified particular antecedents of EfS in the Montessori method of education that existed in the school prior to AuSSI, including the whole child approach, together with the Montessori learning environment, curriculum and values. Following participation in AuSSI, student attitudes and values, knowledge and understandings, and skills and behaviours related to EfS were enhanced for all year levels. However, after 3 years, when specific EfS actions and projects ceased, student EfS outcomes were limited. Furthermore, students' thinking and behaviour indicated a 'silo', rather than whole systems thinking approach to EfS. Teachers perceived the EfS program as highly effective in the initial 3 years after joining AuSSI. Key elements that enhanced EfS included EfS staff champions who had access to EfS networks, leadership support, and
\end{abstract}


active school community involvement in all EfS processes. However, after 3 years of being an AuSSI school, the culmination of reduced leadership support for EfS, lack of staff training, vague designation of staff with EfS responsibilities and inadequate community involvement, resulted in cessation of the EfS program. Teacher perceptions on whole systems thinking revealed alignment between Montessori philosophy, EfS and whole system thinking was more in theory than in practice.

Through an in-depth longitudinal case study of a school this research highlighted the importance of whole school EfS professional learning, embedding EfS and whole systems thinking across the curriculum at all year levels, whole school support, and the usefulness of a sustainability continuum that recognises the complex, dynamic interplay of issues involved in a school's EfS journey. It is strongly recommended that improvements to pre-service teacher education in EfS are implemented, and a review of the AuSSI toolkit is conducted to refine EfS evaluation processes and to target the specific EfS needs of teachers at different stages of schooling, as well as to enhance understanding and implementation of the whole systems thinking approach. Finally, EfS professional learning for all school staff in all schools is warranted to enhance depth of EfS engagement.

\section{Key Publications Generated}

The following refereed publications have resulted from the research described in this dissertation:

Lewis, E., Nielsen, L., Pearson, J., \& Baudains, C.M. (2012). Turtle watch: Enhancing science engagement. SCIOS: Journal of the Science Teachers' Association of Western Australia, 48(2), 14-18.

Lewis, E., Mansfield, C., \& Baudains, C.M. (2010). Going on a turtle egg hunt and other adventures: Education for sustainability in early childhood. Australian Journal of Early Childhood, 35(4), online annex.

Lewis, E., Baudains, C.M., \& Mansfield, C. (2009). The impact of AuSSI-WA at a primary school. Australian Journal of Environmental Education, 25, 45-58.

Lewis, E., Baudains, C.M., \& Mansfield, C. (2009). Engaging students in science: Turtle nestwatch. Teaching Science: The Journal of the Australian Science Teachers Association, 55(1), 50-53.

Lewis, E., Mansfield, C., Baudains, C., Marcus, L., \& Dundas, B. (2008). Healing the swan: Integrating science. SCIOS: Journal of the Science Teachers' Association of Western Australia, 44(3), 16-19.

Lewis, E., Mansfield, C., \& Baudains, C.M. (2008). Getting down and dirty: Values in education for sustainability. Issues in Educational Research, 18(2), 138-155.

Lewis, E., Baudains, C.M., \& Mansfield, C. (2008). Nestwatch project: The oblong turtle. Western Wildlife, 12(3), 8-9.

Lewis, E., Baudains, C.M., \& Mansfield, C. (2008). Making waves: Engaging science projects. SCIOS: Journal of the Science Teachers' Association of Western Australia, 44(2), 18-19.

Lewis, E., \& Baudains, C.M. (2007). Whole systems thinking: Education for sustainability at a Montessori school. Eingana: Journal of the Victorian Association of Environmental Education, 30(1), 9-11. 
Lewis, E., \& Baudains, C.M. (2007). Raining frogs: An education for sustainability project. SCIOS: Journal of the Science Teachers' Association of Western Australia, 43(3), 25-29.

\section{Citation and Digital Source for Thesis:}

Lewis, E. (2012). Impact of education for sustainability at a Montessori primary school: From silos to systems thinking. Unpublished doctoral thesis, Murdoch University, Australia. Retrieved from http://researchrepository.murdoch.edu.au/12034/

\section{Author Biography}

Elaine Lewis continues to have close research links with Murdoch University in relation to her school work for the Department of Education (WA). In her capacity as Cross Curriculum Coach at an independent public school in Perth (WA), she works with students and teachers, as well as conducting school-based research and professional learning for teachers in the south-west of the state. Elaine has worked as a teacher, across K-7, for many years and in 2008 was awarded the de Laeter Medal for 'Outstanding Contribution to Science Teaching'. She serves on the management committees of the Australian Association for Environmental Education - WA Chapter and the One World Centre Inc (WA), and in these roles is involved in many school and community-based EfS initiatives. In 2012 Elaine was presented with the national 'Educator of the Year' award by the Australian Association for Environmental Education. She has experience as a coordinator in environmental education at Murdoch University and as a lecturer in education at Edith Cowan University Australia. 